University of Warwick institutional repository

This paper is made available online in accordance with

publisher policies. Please scroll down to view the document

itself. Please refer to the repository record for this item and our

policy information available from the repository home page for further information.

To see the final version of this paper please visit the publisher's website. Access to the published version may require a subscription.

Author(s: Pirie, Iain

Article Title: Economic Crisis and the Construction of a Neo-Liberal

Regulatory Regime in Korea

Year of publication: 2009

Link to published version: http://dxd.doi.org/10.1179/102452906X92000

Publisher statement: None 


\title{
Economic Crisis and the Construction of a Neo-Liberal Regulatory Regime in Korea
}

\author{
IAIN PIRIE \\ Department of Politics and International Studies, Warwick University, \\ Coventry CV4 7AL, UK
}

\begin{abstract}
A consistent theme of the literature on the ontology of the 1997 South Korean crisis is the key role played by regulatory failures and the growing weakness of the state. This paper seeks to briefly highlight both the insights and the limitations of this approach to understanding the crisis. Having done so, we shall set out the argument that the crisis created an opportunity for reformist Korean élites to advance their longstanding, but previously frustrated, project to create a comprehensive unambiguously neo-liberal regulatory regime. This paper will also seek to highlight the implications of our reading of the development of the Korean political economy for broader debates on economic liberalisation, crisis and the future of the developmental state.
\end{abstract}

KEY WORDS Globalisation, South Korea, Liberalisation, Crisis, Regulation.

The 1997 South Korean crisis was an event of first order importance. Korea was by the beginning of the 1990s firmly established as an exemplar of successful state-led capitalist development and poised to graduate into the ranks of the core capitalist economies. Did the crisis represent a blip in Korea's historic economic ascent or something more fundamental? While it quickly became clear that the crisis did not mark the end of capitalist development in Korea, debates still rage as to the extent to which the new post-crisis growth regime bears the hallmarks of Korea's dirigiste past or alternatively conforms to global neo-liberal norms (Emery 2001; Shin and Chang 2003; Weiss 2003; Ministry of Finance and Economy 2004). Furthermore, the crisis has raised all sorts of questions about the continued viability of distinct national economic models in an increasingly integrated world economy and the desirability of economic liberalisation.

This article has two central objectives. The first is to expose the limits of an understanding of the crisis that focuses on 'regulatory' failures and expose the limitations of the (non) debate between Keynesian and Neo-liberal scholars concerning the management of the process of economic liberalisation. The second, and more significant, objective of this paper is to demonstrate how Korean élites have used the crisis to create a new unambiguously neo-liberal regulatory regime. Something they had desired to do so for some time but had previously found impossible.

E-mail address: I.J.Pirie@warwick.ac.uk 
In order to advance these arguments this paper is divided into three parts. The first part seeks to place the Korean state's efforts to reform its economy in the 1980s and 1990s within the context of wider changes that were taking place in the global economy. The second part directly addresses both the deficiencies of the existing literature on the crisis and argues that the crisis must be understood as an unavoidable aspect of the process of economic liberalisation in Korea. The third section examines how the Korean state-capital complex acted in the wake of the crisis to create a neo-liberal regulatory regime. Having set out the broad arguments about how the crisis created political space for reform we seek to advance a alternative reading of corporate governance reform to that offered within the existing academic literature and highlight the importance of changes in systems of financial regulation that have taken place since 1997.

\section{The Crisis of the Korean Developmental State and Global Structural Change}

As has been well documented by a wide range of scholars the basic objective of the Korean developmental state project was to develop industrial self-sufficiency and independent exporting capacity across a range of major global industries (Amsden 1989; Woo 1991; Kong 2000). In order to achieve this objective the state placed selected firms on a steroid diet of cheap state directed credit. The dependency of major Korean firms on external financing was much greater than their counterparts in the advanced capitalist countries (see below for details). Furthermore, firms were encouraged to develop capacity in strategically important sectors even when the prospects for realising substantial profits from these investments was very poor in the short term and uncertain in the longer term. The Korean state effectively sought to disregard the limits of the market, or at the very least adopt a flexible approach towards these limits, and insure that investments were made even when they would weaken the financial position of key national capitals. In the language of Marxist economics the state actively promoted the overaccumulation of capital (Clarke 1992).

As has been equally well documented these policies proved highly effective and Korea enjoyed some of the highest growth rates in the world over the course of the 1960s, 1970s and 1980s. However, changes in the global organisation of production whose origins can be traced back to the 1960s but which gathered pace in 1980s and 1990s together with the rise of the global financial market served to undermine the viability of this project. Two distinct but related aspects of the process of global economic change (globalisation) in particular presented a problem for the Korean state-led development model. ${ }^{1}$

First, some of the most dramatic technological developments over the last 30 years have occurred in 'space-shrinking' technologies. It is now possible to move information from one 'centre of economic activity' to another almost instantaneously and relatively cheaply, regardless of the geographical distances involved (Dicken 1998). The reduction in the costs of transferring information between geographically dispersed economic centres has been paralleled by equally significant developments in global transportation systems. As a result of both technological change and global deregulation, the costs of air travel are now a fraction of what they were in the late 1960s. Less dramatically, but in some respects no less importantly, shipping costs have also fallen significantly as a result of developments in container technology and shipbuilding processes (Strange 1994). Taken as a totality advances in communications and transport technology have made it possible for integrated supranational production systems and a unified real-time global financial system to 
develop. These developments challenge the basic logic that underpinned industrial policy in Korea and other developmental states, the axiomatic belief that strong national firms equal a strong national economy. As firms denationalise an increasing array of their activities a process the state must encourage if nominally domestically based firms are to remain competitive - it becomes increasingly difficult to justify support for historically domestically-based firms. While the industrial structures of the post-war era obliged states to focus all their efforts on promoting large, nationally-based firms, it is clear that contemporary economic structures place an entirely different set of demands upon the state (Stopford and Strange 1991; Dunning 1997; Strange 1998; Prakash and Hart 1999).

Second, the technological barriers to achieving competitiveness in key global industries have massively increased over the last three decades (Stopford and Strange 1991; Dunning 1997). The proportion of Gross Domestic Product (GDP) all the leading industrialised nations devoted to non-defence related research and development (R\&D) in 1990 was much greater than it had been a decade earlier (Dunning 1993: 63).

The growth of R\&D costs was particularly important in those industries within which leading Korean firms sought to compete. By the mid 1990s it was not uncommon for major car manufacturers, such as General Motors and Ford, to invest $\$ 5$ billion in developing a new model (Dicken 1998: 326). Today we could reasonably expect a major firm to invest over $\$ 8$ billion in developing a new model (Dicken 2003: 364). The picture was just as bleak in the electronics sector. The annual R\&D budgets of leading global electronics firms were well in excess of $\$ 6$ billion by the end of the 1980s. The increasing costs of achieving/ maintaining any form of competitiveness in the global electronics industry cannot be measured by simply focusing on direct $\mathrm{R} \& \mathrm{D}$ expenditures. Rather, we must also take into account how the changing technologies of production have increased the levels of fixed capital investment necessary to compete effectively in the world market. The most significant example of the impact of technological change on fixed capital costs relates to semiconductors where the cost of establishing a new plant has risen from $\$ 2$ million in the late 1960s to over $\$ 3$ billion today (ibid.). As a result of technological change in many industries in the contemporary global economy any attempt to delineate between fixed investment and R\&D costs is highly problematic.

While major consumer electronics, car and semiconductor firms from Europe, Japan and the United States of America (USA) were, and are, in a position to finance such increased costs primarily from retained profits the situation in Korea was rather different. Between 1970 and 1989 only 29 per cent of total Korean investments were financed from internal funds (Chang and Park 2004: 39). This compares with over 60 per cent in the USA, Germany and Japan (ibid.). These figures reflected both the starting position and the ambition of key Korean firms. ${ }^{2}$ Korean firms were seeking to grow rapidly from a low base, to break into new industries and move from peripheral low valued added positions to more established technologically sophisticated high value added positions within highly oligopolistic markets. Their ability to employ internal firms was necessarily lower than the industry leaders they sought to emulate who were not only larger but operated at the higher end of the market (Bello and Rosenfeld 1990: 17-173; Ungson et al. 1997: 134-163; van Hoesel 1999). To put it crudely, Korean firms were playing 'catch up' and without secure profit streams to draw upon they had no choice but to rely heavily on external finance if they were to make the investments in $R \& D$ and fixed capital necessary to achieve their ambitions. 
Given that Korean firms were dependent on the financial system to provide the funds necessary for them to achieve/sustain technological competitiveness in key global industries it is critical that we examine the capacity of the financial system to actually do so. Logically there were clear limits to the capacity of the Korean financial system to supply the necessary funds, although these have largely been ignored in the existing literature. The problem was not that the Korean financial system was incapable of funding a single \$5-6 billion investment. Rather, it was that such a investment would amount to well over 1 per cent of peak pre-crisis GDP and there were tight objective limits on how many multibillion dollar investments the Korean financial system could reasonably be expected to fund (Kong 2000: 23). The state was certainly in no position to fund the development of independent exporting capacity across a range of major global industries. In a fundamental sense, therefore, the limits of the developmental state project, which was based upon the idea that the state could finance the development of such capacity, had been reached by the mid 1980s.

There is ample evidence that key elements within the Korean state-capital complex believed that the long-term competitiveness of Korean firms was, to a large extent, dependent on their ability to access global capital markets. This view was expressed particularly clearly by the chaebols' collective mouthpiece, the Federation of Korean Industries (FKI), in their opening missive to the Kim Young-Sam administration in 1992. The FKI complained bitterly to the new president about the impact of controls on foreign borrowing by Korean firms and high domestic interest rates on national industrial competitiveness (Kong 2000: 161). The views expressed within this key publication were entirely consistent with those articulated in the FKI's annual reports since 1988 (Kim 1999). These reports had consistently demanded that restrictions on borrowing from international banks and the issue of securities on international markets be lifted. These firms wanted the freedom to raise money on global markets, where real interest rates were around half domestic levels, in the same manner as their counterparts elsewhere in the world. ${ }^{3}$ In the late 1980 s leading politicians, including figures close to the than deputy prime minister and head of the Economic Planning Board (EPB), Cho Soon, made similar statements to the FKI about the potential for problems in domestic systems of industrial finance to undermine Korea's competitiveness in key global industries (Gills 1996: 681).

None of this is to suggest that capital account liberalisation offered any sort of panacea. As this paper consistently argues Korean firms had historically over invested (ignored the limits of the market). These practices had created severe firm level financial fragilities. As processes of financial opening exposed financially weak firms to the judgements of the global market this would, in the short/medium term at least, reduce the level of aggregate investment as firms were forced to rationalise or face bankruptcy. Rather, than portraying liberalisation as a cure all within this paper we simply seek to expose the limits of the traditional Korean developmental model based upon state financing of the development of independent exporting capacity in a changing global economy and the pressures on the state to liberalise its economy.

The problems that were presented by the simple growth in $\mathrm{R} \& \mathrm{D}$ costs to individual Korean firms and the state's own economic nationalist project were compounded by other changes in global systems of production and innovation. Firm's technological competitiveness is increasingly dependent on their capacity to internationalise R\&D programmes through both intra-firm links and direct investments. As Dunning $(1993 ; 1997)$ work on multinational firms demonstrates an increasingly important rationale underpinning much foreign investment is a desire to strengthen firm level technological capacities by both 
acquiring foreign firms with cutting edge technology and by establishing a presence in particular political economies which have structures that lend support to particular forms of innovation. More important still, than the rise in the levels of foreign direct investment (FDI) whose purpose is to enhance the investing firms technological capacities have been the growing importance of transnational intra-firm technological alliances. As Dunning (1997: 75) argues, 'because of competitive pressures, the huge and rising costs of R\&D and speedier rates of obsolescence, firms - particularly in high-technology sectors - have been increasingly induced to engage in cross broader alliances'. In other words, financial and competitive pressures forced even the largest multinationals to seek alliances in order to reduce the costs associated with developing new technologies. According to Freeman and Hagedoorn (cited in ibid., 75) there were 4192 cross-broader technology based strategic alliances between 1980 and 1989. This figure is just over a tenth of the number of technology based cross-broader alliances the OECD (2001a) suggests took place over the course of the 1990s.

Critically, unlike old licensing agreements with which Korean firms were familiar the new cross border alliances were not simple hierarchical arrangements that reflected the licensee's technological weakness. As such they place an entirely new set of demands on policymakers. Historically, Korean firm's reliance on licensing technology was an unfortunate reality that the state had sought to manage in the short-term in order to limit its adverse impact on both economic performance/national autonomy and to escape from in the medium term by promoting domestic innovation. Unlike dependence on licensing, technology involvement in trans-national alliances as an active research partner is a sign of strength not weakness. It is not something that policymakers concerned with national competitiveness ought to seek an escape from but rather something they must promote.

In a sense firms' ability to effectively compete in major global industries is at least partially dependent on their capacity to move beyond simply being national firms (with certain external linkages) to being more genuinely transnational entities. These changes in the dictates of competitiveness helped undermine the logics underpinning the relatively autocentric Korean developmental state project and encouraged the state to pursue a strategy based upon promoting the economy's deep integration into global circuits of finance and production. The difficulties that the changes in global innovation systems outline above posed for Korea were compounded by the strengthening of international intellectual property rights which accompanied the creation of the World Trade Organisation that prevented Korean firms plagiarising technologies in the same manner as they had as a matter of routine in the past (Matthews 2002).

As we have made clear in this section, from the late 1970s powerful pressures emulating from the global economy served to create a powerful impetus for Korea to abandon the old state-led developmental project based upon 'controlled' interaction with the global economy and to pursue neo-liberal reform. The state's attempts to liberalise the economy and promote Korea's deep integration into global circuits of finance and production in the years preceding the crisis must, therefore, be understood as a rational attempt to secure Korea's position as a site of accumulation within a changing global economy. Paradoxically, however, the decision to pursue liberalisation and economic opening also made a crisis of a similar scale to that which occurred in 1997 inevitable. It is to the causes of the crisis and the weaknesses of existing explanations of the crisis which focus on regulatory failure we now turn. 


\section{The Origins of the Crisis and the Fetishisation of Regulation}

Since the onset of the Korean crisis in 1997 countless journal articles, book chapters and single authored research monographs have sought to explain the causes of the crisis. While the positions taken within much of this literature are highly nuanced and complex it is nevertheless possible to divide the existing literature into two broad opposing camps. First, there are those state institutionalist/Keynesian scholars who essentially argue that the erroneous decision to pursue neo-liberal reform in the 1980s and 1990s lay behind the crisis, or more commonly that while some limited form of liberalisation may have been desirable that Korea went too far too fast. Korea's negative experience with liberalisation is often compared with Taiwan's more positive experiences with 'state managed' strictly controlled financial liberalisation (Lee and Kim 2000; Weiss 2000; Shin and Chang 2003; Thurbon 2003). Second, there are those neo-liberals who understand Korea's problems as being a result of the continuation of selective dirigiste interventions and illiberal non-market-based controls. At the same time, however, mainstream neo-liberals attach at least equal importance to the failure to construct proper market-based regulatory systems as to problems created by residual aspects of the old dirigiste command system (Gobat 1998; OECD 1998; Balifio and Ubide 1999; Graham 2003). It is too simple, therefore, to categorise the principal divisions within the literature as being between those scholars who argue that there was too much intervention in the economy and those who argue that there was too little. Rather, there is a reasonably broad consensus which only radical free marketeers and those scholars who are simply opposed to any form of capital account liberalisation stand outside which understands the Korean crisis as being a result of regulatory failures. For the large majority of scholars the crisis stemmed from the failure of the state to discipline domestic firms and financial institutions either directly or through more market-based controls. ${ }^{4}$ While the exact nature of the regulation that neo-liberals and state-institutionalists advocate differs somewhat in practice the 'reformed' developmental states model that state-institutionalists promote shares a significant amount in common with the strong neo-liberal regulatory state (World Bank 2002; Weiss 2003).

This academic consensus on the crisis reflected both the global ideational environment and the empirical reality within Korea. Internationally, the élite mantra of the 1980s 'shock therapy and markets' had by the time of the Korean crisis shifted to 'carefully sequenced liberalisation and the strong market enabling regulatory state' (World Bank 1997; 2002). More significantly, it is an undisputable fact that as the Korean state progressively abandoned old dirigiste control systems it conspicuously failed to develop new neo-liberal systems of regulation based upon international norms. In a sense a regulatory vacuum emerged. By the early 1990s the state had surrendered its dominant position within the financial system and wound down licensing control systems. As a result of these changes it was no longer in a position to directly discipline major firms in the same manner as it had in the past. At the same time, in the absence of the basic legal/institutional foundations of a market economy firms and financial institutions were not subject to 'normal' financial disciplines.

As a result of a lack of effective oversight by either the state or the market, the controlling shareholders (who invariably owed considerably less than 50 per cent of total equity) of leading Korean firms enjoyed complete freedom to run these entities as they pleased. Many of their decisions were impossible to justify according to any profitability test or rational notion of 'national' economic interest. Two of the more spectacular examples of the 
chaebol's extreme profligacy during the lead up to the crisis were Hanro's decision to borrow $\$ 6$ billion in order to build a steel mill and Samsung's decision to enter the car industry. ${ }^{5}$ Hanro had a dreadful track record in manufacturing and, unsurprisingly the steel mill was never completed and the entire group collapsed in early 1997 (Chang et al. 1998: 740; von Hoesel 1999: 75). For different, but related, reasons Samsung's investments in car production were equally problematic. Samsung lacked strength in machine-related industries and, more importantly, the Korean, and global, car industries were already suffering acute problems of overcapacity (Chang et al. 1998: 740-741). Samsung motors never recorded a profit before its sale, at a price that fully reflected its loss making status, to Renault in 2000 . The best overall indicator of the chaebol's wastefulness is the fact that the chaebol, collectively, were basically making no money by 1996 (Hahm 2003: 94).

While appropriate regulation cannot cancel out capitalism's inherent tendencies towards crisis the absence of such frameworks will allow perverse behaviour by firms and financial institutions and create avoidable volatility. Market disciplines do not function automatically. Rather, they depend on the existence of strong legal institutions (systems of financial regulation, strong bankruptcy and accountancy laws, and statutory corporate governance standards) if they are to function properly. Moreover, the construction of strong explicitly neo-liberal systems of financial regulation and corporate governance has been key to the establishment of a relatively stable growth regime in post-crisis Korea.

Yet the conventional analysis of regulatory failures in pre-crisis Korea is problematic. The essential problem with much of this analysis is that it either implicitly or explicitly underplays the extent of the problems that any substantive form of capital account liberalisation posed for the Korean state.

These limitations stem principally from a failure to understand the full extent of the problems that beset firms and financial institutions within an increasingly open economy. The scale of the challenge the Korean state faced is not well captured by discussions of regulatory failure. Integral elements of the traditional growth regime were essentially incommensurate with the demands of competitiveness within a more open economy.

Leading Korean chaebol had always maintained very high debt burdens, subordinated concerns about ordinary profitability to the pursuit of expansion and market share, and used opaque webs of inter-firm debt guarantees to support unprofitable firms within their groups. The average debt-to-equity ratio of the Korean corporate sector was over 300 per cent throughout the 1960s and 1970s (Joh 2001: 124). At the same time the profitability of the Korean sector was, depending on how we measure it, either pathologically weak or mediocre.

The question of how profitable Korean firms actually were in the 1970s, 1980s and 1990s has been the subject of intense debate since the crisis. Defenders of the developmental state argue that historically the profitability of the Korean corporate sector had been acceptable if unspectacular. In order to support their arguments such scholars are able to marshal a array of figures that indicate that operating profits in Korea were similar or even marginally higher than in the USA or Japan (Chang and Park 2004: 28-29). This point is well made and we have no wish to contest it. However, it is also irrelevant to the arguments advanced within this paper.

The critical point is that levels of ordinary profitability, profitability after financial expenses, were chronically low. When we analyse the financial fragility of the corporate sector ordinary profitability not operating profitability is the appropriate measure of firms' performance. Even prominent defenders of the Korean developmental state freely admit 
that levels of ordinary profitability had historically been weak in Korea (Chang and Park 2004; Crotty and Lee 2004). There is no debate about this. According to Chang and Park (2004: 28) the average level of ordinary income to sales was 2.8 per cent in Korea between 1973 and 1996. To put this figure into perspective, the level of ordinary income to sales in Japan during its high growth period between 1955 and 1973 was 4.3 per cent (ibid.). Equally importantly, as Figure 1, which is taken from Crotty and Lee (2004: 49), demonstrates levels of ordinary income to assets in the Korean corporate sector between 1971 and 1997 were consistently and substantially (on average slightly over 1.5 per cent) lower than the corresponding figures for Japan. The levels of ordinary income to assets in the two other economies, Taiwan and the USA, that Crotty and Lee, defenders of the Korean state-led development model, employ in there analysis are much higher than the Korean or Japanese figures over the same time period.

More evidence of the willingness of Korean firms to ignore the limits of the market and make investments which weakened their financial position is provided by the fact that the return on capital employed had persistently hovered perilously close to or even below the cost of capital (Lim et al. 2003: 14). While this may be a relatively normal condition of business in developed states the implications of the cost of capital being in excess of returns are more serious in Korea given firms' dependence upon external funds. Leading Korean firms had always existed in a state of at best marginal solvency. In the wake of the crisis these practices were, rather predictability, castigated as being inherently dysfunctional. Yet these

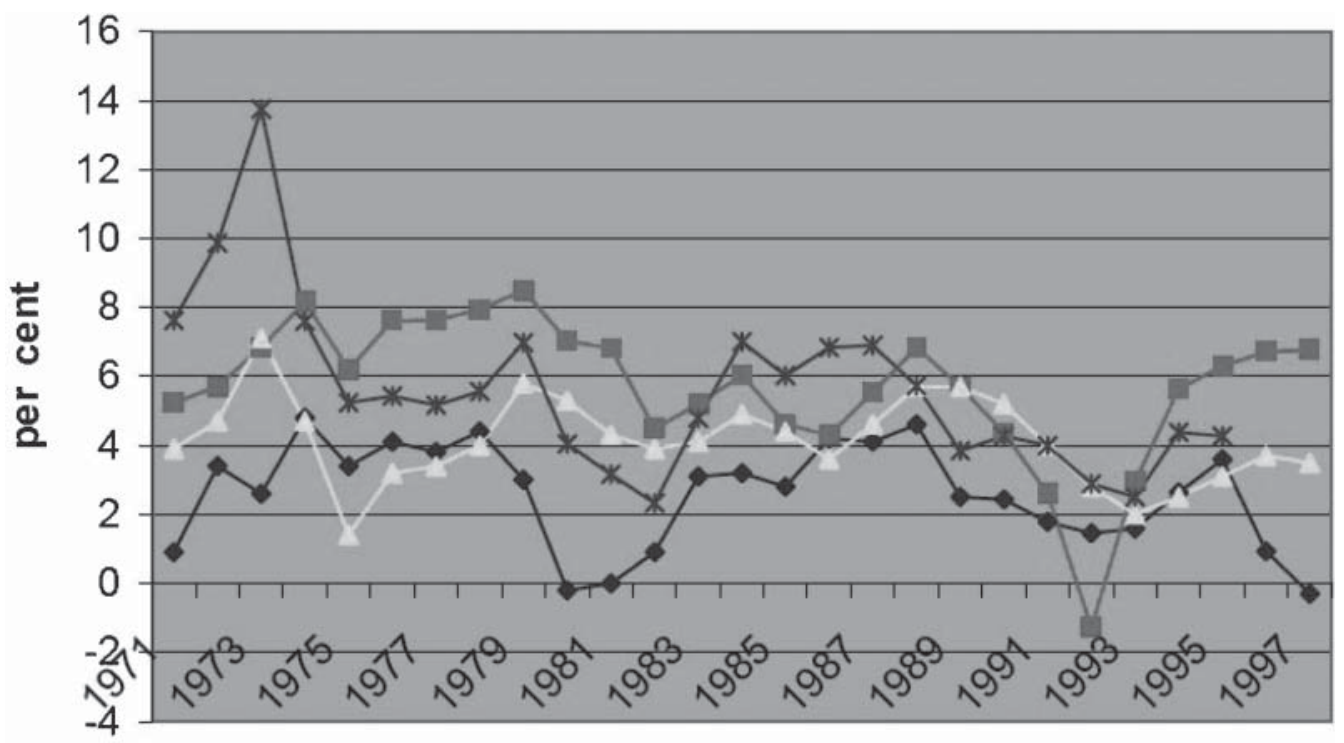

year

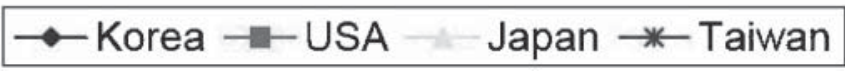

Source: Crotty and Lee (2004: 49).

Fig. 1. Levels of ordinary profit to assets in Korea, the USA, Japan and Taiwan between 1973-1997. 
were the same practices that had fuelled one of the most spectacular economic ascents in history. Within a closed financial system the vulnerabilities that were created by the subordination of concerns about ordinary profitability and solvency to expansion could be managed by the bureaucracy and private sector insiders, the illusion of solvency could be maintained. The gradual unwinding of capital controls increasingly exposed firms and financial institutions to the judgements of the global financial market and made it impossible for vulnerabilities to be 'managed' in the same manner as they had been in the past.

The size of the challenge that economic liberalisation and deep integration into global circuits of finance and production posed for the Korean state must not be underestimated. The state had to do nothing less than completely remake the corporate and financial sectors. A significant minority of Korea's major firms had to be allowed to fail, other firms had to have their debts restructured and be forced to rationalise their activities, and large elements of the effectively insolvent financial system had to be nationalised and recapitalised.

While not necessarily irrelevant the preservation of selective dirigiste controls, to coordinate private sectors investments, did not offer a real solution to the fundamental problems of the Korean economy. The arguments that the crisis could have been averted through appropriate market-based regulation are also problematic. The point is that given the financial structures of major Korean firms and financial institutions a serious attempt to enforce 'global' standards of financial regulation and corporate governance would have been tantamount to shutting the economy down. A plethora of major financial institutions would have had to close and a credit crunch would have inevitably ensued. In any case if firms had been forced to produce accurate accounts and financial institutions to use forward looking loan classification criteria it is difficult to see how these institutions could have extended credit to many of their traditional clients (OECD 1998: 51-61). To introduce such controls would have been to deliberately invite a full-scale recession and a massive rise in unemployment. In other words, tighter market based regulation could have acted as a stimulus to processes of creative destruction by precipitating a crash which had the potential to create the economic and political space necessary for a new regime of accumulation to be born. Neo-liberal 'prudential' supervision could not, however, as its conventional advocates claim, have offered any defence against a major crisis within the Korean context.

While certain governments may in the past have been able to deliberately provoke crisis in order to further their long-term political and economic ambitions it was completely unrealistic to expect the Korean government to do so. It may be clear in retrospect that the contradictions within the Korean regime of accumulation were reaching crisis point by the early 1990s the casual observer could be forgiven for believing everything was well. Growth rarely dipped below 6 per cent between 1981 and 1996, ultra full employment was the norm and the average Korean found themselves in the happy position of enjoying a steadily rising income (Amsden 1989: 56; Kong 2000: 23). Given the prevailing macroeconomic environment it was completely unrealistic to expect any government to undertake a painful restructuring process. In any case there is a certain simple logic to the argument that it was as well to milk the existing regime of accumulation for all it was worth and be as rich as possible at the point of its final collapse. Why endure a crisis before you absolutely have to?

If we accept the arguments advanced here regarding the intractability of the problems that Korea faced, the frequent claims that the inability of the state to 'manage' the liberalisation process correctly was a result of its weakness or 'faulted' nature lose much of their validity (Lee 2000; Park 2002). The state did not fail to accomplish a moderately difficult task. Rather, by failing to prevent liberalisation resulting in a major crisis the state 
simply failed to do the impossible. This is not, of course, to say that the severity of the crisis could not have been lessened somewhat if the state had demonstrated perfect foresight.

While it was unrealistic to have expected the state to take serious action to address the deep-rooted problems that dogged the economy prior to 1997 the economic crisis created a political space that made reform possible. It is to how the crisis undermined the forces opposed to the construction of an effective neo-liberal regulatory regime and the key reforms that have been enacted since the crisis we now turn.

\section{The Politics of Crisis and the Construction of a Neo-Liberal Regulatory Regime}

The 1997 crisis did not mark the end of capitalist accumulation in Korea. Rather, it represented a necessary part of the transition to a new relatively stable and dynamic neo-liberal regime of accumulation. The crisis and the intervention of the IMF altered the balance of power within the Korean state-capital complex and created the political space necessary to address the problems that beset the economy and to construct a fundamentally new neoliberal economy. The economic crisis, and the intervention of the International Monetary Fund (IMF), fundamentally altered the balance of power between the more reform-oriented and conservative members of the Korean élite in favour of the former. There had long been significant elements of the Korean state élite that had sought to construct a new comprehensive neo-liberal regulatory regime. Prior to the 1997 crisis the financial reform committee, which was appointed by the government, had called for the creation of a powerful unified financial regulator and central bank reform (Emery 2001: 44). Furthermore, in the years immediately preceding the crisis competition law was strengthened, the first steps towards the creation of an independent telecommunications regulator were taken and the rules governing the formation of new regulations were reformed along neo-liberal lines (see OECD 2000a). The purpose of highlighting these measures is not to suggest that they represented solid foundations upon which to construct a new neo-liberal regulatory regime. They did not. Rather, it is simply to demonstrate that a new policy agenda based upon neo-liberal re-regulation did not simply emerge out of the ether in late 1997.

The election of Kim Dae-Jung, who owed his victory at least in part to the economic crisis, to the Presidency in late 1997 provided a significant boost to reformist élites. Kim Dae-Jung was a genuine political outsider who had long been critical of the symbiotic relationship between major firms and the state and had called for a fundamental reorganisation of the economy along essentially neo-liberal lines (see Kim 1996). In marked contrast to his predecessors Kim Dae-Jung's views regarding the political/social problems that the domination of a handful of chaebol caused made him a natural supporter of a neo-liberal project which sought to promote greater foreign investment, investment which promised to undermine the dominance of the chaebol.

At the same time, the crisis itself effectively destroyed the major chaebol's power to veto economic policies that they believed threatened their interests. The threat that policies which forced major firms to reform would negatively affect investment levels/growth was a hollow one given that investment had already fallen through the floor and the economy was contracting rapidly. Furthermore, in the immediate wake of the crisis the state was effectively forced to nationalise large parts of the failing financial system and regained the financial control over major firms that it had enjoyed prior to economic liberalisation in the 1980s and 1990s. As has been well documented economic crisis globally have often, 
somewhat paradoxically, strengthened the state by affording it a new freedom to promote economic restructuring (on this point see Jessop (1988) and Bonefeld (1993) on crisis and economic restructuring in 1980s Britain).

Most significantly of all, the crisis forced even the most conservative members of the state-capital complex and the general public at large to face the reality that Korea's future as a major centre of capitalist accumulation was dependent upon the adoption of a radical programme of reform. Even Korea's radical trade unions were forced to publicly acknowledge the need for radical restructuring in the immediate wake of the crisis (Cumings 1999: 37-38; Kim and Moon 2000: 63-64). Korea's consistent failure to address the structural problems that beset its economy was no longer something that simply had serious long-term consequences and could be safely ignored in the short-term. In the wake of the crisis, the choice was no longer between strong short-term growth and deflationary restructuring, but rather between radical restructuring and national decline.

The 1997 crisis did not end debate about economic policy within Korea. However, it fundamentally altered the terms of the debate. While individual policies and decisions continued to be the subject of contestation the nationalist/pro-chaebol right and the socialist left proved equally incapable of presenting a coherent convincing alternative to radical neo-liberal reform. Although the short-term effects of tackling corporate debt problems and restructuring the financial sector may have been deflationary, to allow firms and financial institutions to maintain precarious financial structures was to guarantee that history would repeat itself.

Given the internal pressures for reform we may swiftly dispense with any understanding of the International Monetary Fund's (IMF) role in the crisis that understands this institution as imposing certain conditions on a reluctant Korean state. Rather, we must understand the IMF as playing an important role in allowing the Korean state to deflect criticism it would have otherwise received for painful but necessary measures. External intervention strengthened rather than weakened the Korean state. ${ }^{6}$

In the short-term the 'neo-liberal' project, paradoxically, involved very heavy direct state intervention in the economy. The state nationalised major failing financial institutions, effectively ordered the chaebol to restructure, played a decisive role in selling major ailing firms and banks to foreign investors, and coordinated tens of billions of dollars worth of debt restructuring/ rationalisation agreements (OECD 1999; Richards et al. 2002; Haggard et al. 2003; Pirie 2005a). Heavy direct state intervention in the economy was not a substitute for tightening market-based regulation but rather a compliment to regulatory reform. Tightening regulatory standards in an environment where major banks and firms were clearly insolvent and unprofitable inevitably created extensive and serious problems. The state had to take responsibility for managing these problems and creating an economy 'fit' to be subjected to market-based neo-liberal regulation. Yet by its very nature the neo-liberal state must be a regulatory state that creates frameworks which allow market disciplines to function effectively, not a state that intervenes directly to determine market outcomes. Selective intervention, while important, was simply an instrument to expediate post-crisis restructuring. Strong market-based regulatory frameworks, on the other hand, were the permanent core of the neo-liberal project. Analysis of these frameworks is important because their success in effectively disciplining domestic capital is likely to be a key determinate of Korea's ability to continue its long-term economic ascent. Furthermore, it is, at least, partly through the analysis of these regulatory structures that we can determine whether or not contemporary Korea may accurately be described as a neo-liberal state. In 
order to advance the argument that a neo-liberal state form, or more precisely disciplinary regime, is consolidating in Korea and highlight the forces driving this project we shall focus on key reforms to systems of corporate governance and financial regulation.

\section{Corporate Governance}

Since the 1997 crisis a considerable amount of academic attention has been focused on the reform of systems of corporate governance in Korea (Chung and Wang 2001; Jang and Kim 2002; Cho 2003; Jwa and Lee 2004). The level of attention that has been devoted to the reform of corporate governance reflects both the substantive importance of corporate governance as a policy issue and the scale of formal changes in corporate governance that have taken place in Korea since 1997. Although it may be difficult to ascertain a direct link between improved corporate governance (transparency and accountability) and firms' performance on a global level in the Korean case there can be little doubt that improving corporate governance was key to improving firms' performance.

As our discussion of the crisis makes clear and has been well documented by numerous scholars (including Chang et al. 1998; Chang 2003; Kim and Lee 2003; Hahm 2004), the behaviour of controlling shareholders in the years leading up to the crisis (when free from both market and state controls) was nothing short of pathological. Leading chaebol sacrificed profitability and focus on developing strong firms (their core competencies) to quixotic expansion plans which ultimately undermined the financial stability, through transfer payments and debt guarantees, of the strongest Korean firms. As we have already said, there are numerous examples of massive investments in new business areas by the chaebol which have not simply been condemned with the benefit of hindsight but which were roundly criticised when they were instigated. The ultimate indictor of the profligacy of major Korean firms was the simple fact that they were effectively making no money whatsoever on the eve of the 1997 crisis.? $^{7}$

Improved standards of corporate governance do not represent a silver bullet that promised to cure all that ailed the economy. However, on the basis of historical experience there was absolutely no reason to believe that controlling shareholders would focus on maintaining/enhancing profitability and managing debt levels in the absence of powerful external controls. A precondition to actually improving profitability and the financial condition of the corporate sector was to insure that controlling shareholders actually focused on these objectives. Of course the fact that firms may focus on achieving profitability and improving financial soundness in no way insures that they will achieve these objectives. Nevertheless, if firms do not even prioritise these objectives it is almost certain that they will suffer from low profitability and will have precarious financial structures.

The need to properly discipline controlling shareholders, through market based or more dirigiste means, as a prerequisite to improving corporate performance is almost universally acknowledged within the literature on the Korean political economy. Equally, the extent of the formal changes in systems of corporate governance that have taken place in Korea is not contested. The core legal elements of a modern market based (neo-liberal) system of corporate governance are clearly in place in contemporary Korea. A concerted effort has been made to bring Korean accounting standards fully in line with US Generally Accepted Accounting Principles. More precisely, major changes have included requirements for elimination of deferred assets and liabilities; the introduction of new rules for the accounting of derivatives; the adoption of limits on asset revaluation; and a reduction in the 
scope for shifting between different accounting standards in corporate accounts' (OECD 1999: 116). Moreover, 'reporting entities' (firms) are now required to produce consolidated financial statements that include the accounts of any subsidiaries or controlled companies. Additionally, the chaebol are obliged to produce combined financial statements. The significance of these changes outlined above is buttressed by reforms that seek to enhance the independence of auditors (see OECD 2001b: 130).

At the same time the legal protections minority shareholders enjoy from expropriation have been significantly enhanced. The levels of ownership required to demand the inspection of books, the punishment of a director for misconduct, to file a derivative suit or call for a special general meeting have all been lowered from 5 per cent to between 1.5 per cent and 0.05 per cent (OECD 1999: 113; 2001b: 128). Moreover, the fiduciary duties of controlling shareholders has been significantly enhanced by the 1998 Commercial Code that makes it clear that de facto directors shall be treated in the same manner as de jure directors (Kim and Jeong 2000).

The pressures on controlling shareholders not simply to act in a legally appropriate manner but to deliver improved financial performance have been intensified by the liberalisation of all forms of mergers and acquisitions (M\&A) (Chung and Wang 2001: 108 110). The new systems of corporate governance that seek to force managers to focus on enhancing shareholder value/profitability are all underpinned by reforms which seek to create a functioning bankruptcy system. Throughout the 1960s, 1970s and 1980s it was normal for bankruptcy proceedings in Korea to take the best part of a decade to be resolved and delays of over ten years were far from uncommon (OECD 1999: 120). The new bankruptcy laws that have been introduced since the crisis make it clear that proceedings are to be concluded within one year, and can in many cases be resolved in less than six months (OECD 1999: 120; 2001b: 128). Clearly the construction of a functioning bankruptcy system is an intrinsic element of any serious attempt to impose market disciplines on controlling shareholders.

Despite the extent of the legal changes that have taken place the overwhelming majority of the literature on corporate governance is fairly sceptical about the extent to which systems of governance actually function in practice (Richards et al. 2002: 116-122; Graham 2003: 116-171; Cho 2003; Lim 2003). The argument advanced here is that the existing literature underestimates the effectiveness of corporate governance reform in Korea and the extent to which legal changes have been translated into changes in corporate behaviour. We would stress that the differences between our analysis and that offered in the existing literature are ones of emphasis. Korean systems of corporate governance are far from perfect, as are systems of corporate governance in every major economy. Nevertheless, there have been significant concrete improvements in systems of corporate governance since the crisis.

This is not to say that we ought to be dismissive of the plethora of surveys that highlight the discrepancies between formal changes in systems of corporate governance and the realities on the ground. A 2000 PriceWaterhouse Coopers' report labels Korea as having the lowest standards of transparency among 35 major economies (Graham 2003: 161). Equally, a more recent Credit Agricole survey of Asian corporate governance systems awarded Korea 3.5 out of 10. By way of contrast Singapore received a 7.5 (OECD 2004: 130). However, we should not accept these reports uncritically. In comparing Korea with other major economies these surveys take no account of Korea's starting point. The fact that standards of corporate governance in Korea may be lower than in the USA or Singapore does not necessarily mean that they have not substantially improved. Furthermore, such surveys are 
ultimately based upon the subjective perceptions of specialists who have long experience with systems of Korean corporate governance. Inevitably these perceptions will not simply reflect the present but will be influenced by recent history. The fact that standards of corporate governance have historically been appalling in Korea cannot but distort judgements about the effectiveness of contemporary systems of corporate governance.

The critical source of evidence that demonstrates the effectiveness of the post-crisis corporate governance reform process is the profitability of Korean firms in the years since the crisis, something that is completely ignored in the standard discussions of corporate governance reform in Korea. ${ }^{8}$ While not the only objective of the corporate governance reform programme the key to establishing a new sustainable growth regime was to force controlling shareholders to change their behaviour and eschew expansion in favour of focusing on improving financial performance. In other words, it was vital that Korean firms were actually subject to market disciplines if a new stable growth regime was to be established. Market disciplines which could not function without improved transparency (which allows suppliers of capital to make informed judgements about firms) and a functioning bankruptcy system.

The performance of the Korean corporate sector since the crisis illustrates managers' new focus on improving profitability and financial soundness, how reform has succeeded in effecting a change in corporate behaviour. The average level of ordinary profits within the manufacturing sector rose to 4.7 per cent in 2002, the highest level since 1974 (BOK 2003: 540). To put these figures into perspective, the level of American manufacturing profitability in 2002 was 4.9 per cent (ibid.: 545). More importantly still, levels of ordinary profits in Korea remained at 4.7 per cent in 2003 despite a fall in growth from 6.3 per cent to 3.1 per cent (BOK 2004: 555). A modest increase in the rate of growth to 4.6 per cent in 2004 was accompanied by a rise in the level of ordinary profits in manufacturing to 7.8 per cent, the highest level since 1965 (BOK 2005: 594). The fact that major increases in profitability have been achieved in a mixed macroeconomic environment illustrates the deep structural changes that have taken place in the economy. Improved corporate performance has not been the by-product of a cyclical upturn.

The performance of Korean manufacturers is made all the more remarkable when we consider the particularly severe effect that the crisis had on profitability within this sector, with ordinary profit levels failing to a nadir of -1.8 per cent in 1998 (IMF 2003: 15). The profitability of non-manufacturing firms has risen in parallel with their counterparts in manufacturing since the crisis. In 2004 the all-industry ordinary income to sales ratio rose to 7 per cent, its level since 1968 (BOK 2005: 594).

At the same time as improving profitability, domestic firms have also succeeded in reducing their levels of collective indebtedness. As a result Korean manufacturing firms interest coverage ratios (IRC) rose in 2004 to 483.4 per cent, the highest level since 1962. ${ }^{9}$ This figure is considerably higher than the comparable figure for the USA in 2004 that stood at 397.1 per cent (ibid.: 597). Furthermore, by the end of 2004 manufacturing firms' debt-toequity ratios had fallen to a new record low and the debt-to-equity ratios for the Korean corporate sector as a whole were lower than those for American firms (ibid.: 589). ${ }^{10}$

Given that the most important economic objective of corporate governance reform was to expose firms to greater disciplines and force them to focus on improving profitability we must judge the process of reform as being at least a qualified success. While the mainstream academic and corporate literature on Korea may be sceptical about the effectiveness of 
corporate governance reform it seems that controlling shareholders have fundamentally altered their modus operandi and are focusing on maximising profitability. As we have made clear throughout this paper maximising ordinary profitability had never been a priority for controlling shareholders in major Korean firms. It is impossible to begin to understand changes in long established patterns of behaviour since outside the context of the next of processes of regulatory reforms that served to impose market disciplines/hard budget constraints on controlling shareholders. It is clear that controlling shareholders understand themselves to be operating in a fundamentally new environment.

Of course the fact that the focus of managers on improving profitability has improved does not decisively prove that effective comprehensive systems of market based corporate governance are in place. However, we may reasonably ask how we could ever conclusively prove the existence of such a system. All existing systems of corporate governance are imperfect and it would be easy to highlight cases where corporate governance mechanisms have failed in any major world economies. It would be easy to make a superficially convincing argument that corporate governance systems in every major economy are failing by referring to the various scandals that litter the global financial press. On the other hand, it would require a Herculean effort to conduct the micro-level analysis necessary to prove conclusively that in the majority of cases corporate governance mechanisms operate relatively effectively in any given country. In the absence of limitless resources all we can do within this paper is employ the available evidence in order to advance the argument that corporate governance reform has achieved a great deal in Korea.

Reform of systems of corporate governance has been a key mechanism through which the state has sought to expose major firms to greater market disciplines. At the same time, as reforming systems of corporate governance the state simultaneously sought to overhaul the entire system of financial regulation. The ultimate objective underpinning this overhaul was to ensure that firms were subject to proper financial checks when seeking to raise finance, to enhance market disciplines. The reform of systems of corporate governance and financial regulation must, therefore, be understood as being symbiotically linked. It is to the reform of systems of financial regulation in the wake of the crisis we now turn.

\section{Financial Regulation}

The overhaul of systems of financial regulation since the 1997 crisis has involved two closely related but distinct sets of changes. A concerted effort has been made to bring Korean rules into line with international norms in terms of capital adequacy requirements, loan classification standards and measures of solvency. At the same time the institutional structures of financial and monetary governance have been transformed. The reform of institutional structures is, we would contend, at least as significant as the policy changes that have been enacted. Furthermore, it is impossible to even begin to understand the significance of changes in the rules governing the classification of assets and capital adequacy requirements outside the context of the transformation in the institutional structures of financial/ monetary governance. Despite the substantive importance of institutional reforms these measures are dealt with in a fairly cursory manner within the large majority of the mainstream literature (Emery 2001: 93, 158; Graham 2003: 110-112). The fact that the autonomy of the central bank has been enhanced and that an independent financial regulator has been created is not completely ignored. However, the significance of these reforms is not explored. They are simply acknowledged to have taken place. 
The overall size of the literature focused on the post-crisis financial re-regulation process is minute in comparison to the literature focused on the reform of the corporate sector. Furthermore, the large majority of the literature makes little attempt to assess how formal changes have been translated into concrete outcomes or alternatively demonstrates a clear reluctance to come to any conclusions about the effectiveness of the financial reform programme (see Emery 2001; Graham 2003; Hahm 2004). While not entirely disagreeing with the more negative arguments advanced within the existing literature concerning Korean financial institutions lack of proper risk assessment/ pricing skills or seeking to gloss over the imperfections which clearly exist in regulatory systems the overall tone of our argument is very different. When we look not only at changes in particular laws but at changes in institutional structures and the difficulties that large politically connected firms have experienced raising funds, what is most striking is not the failings but the successes of the reform process. Before we analyse the significance of the key institutional changes that have taken place since the crisis we will outline the major changes in standards of financial regulation.

The new regulatory regime is being built, quite explicitly, around standards of best practice, and guidelines, drawn up by the major international organisations of financial supervisors, most notably the Bank of International Settlements and the International Organisation of Securities Commissions. This attempt to create a regulatory regime based on such standards has led to the enactment of eight particularly important reform measures since the crisis.

First, loan classifications are now determined so as to fully reflect the borrower's ability to pay, not simply past payment performance (FSS 2000: 54). Second, all securities must now be valued on a mark-to-market basis rather than at historic cost. Losses on the securities market cannot, therefore, be concealed as in the past, although as the Enron crisis demonstrates, the mark-to-market accounting system is also far from perfect (OECD 1999: $85)$.

Third, very clear rules have been established to insure that all liabilities are now carried on balance sheet (ibid.: 85). Fourth, the capital adequacy and solvency standards that all institutions are required to meet have been significantly tightened. Fifth, new rules to control foreign currency maturity mismatches and prudential limits on institutions foreign lending exposure, based on international credit ratings, have been established. Sixth, the FSS (Financial Supervisory Service) now conducts ongoing assessments of all institutions' risk management systems and is in continual consultation with private institutions on areas where improvements are necessary (ibid.: 81). Seventh, the requirements for public disclosure of financial standards have been upgraded; statements must now be produced quarterly instead of yearly, and International Accounting Standards must be observed when preparing these statements (ibid.: 82). Finally, the maximum permitted exposure to a single borrower has been reduced from 45 per cent to 25 per cent of total capital (ibid.: 87).

The primary purpose of the financial sector reforms is to subject financial institutions to market disciplines/hard budget constraints. The reforms seek to insure that institutions that are insolvent are unable to disguise losses and are forced to exit the market. At the same time, the new limits on the maximum permitted exposure to a single borrower are designed to limit the extent to which industrial capitals can, as they did in the past, establish financial businesses in order to secure captive sources of finance. The new regulatory demands on financial institutions pressure them to discipline firms by subjecting potential borrowers to tighter financial checks. The process of re-regulation is driven by explicitly neo-liberal 
principles. The argument of certain scholars that the process of financial re-regulation in some way represents a retreat from full-scale neo-liberalism simply demonstrates a profound ignorance about the nature of the contemporary neo-liberal project and the role of the state in this project (see Koo and Maeng 2005; Weiss 2003: 254-256).

The impact of the legal changes outlined above is critically dependent upon regulations being consistently enforced, on regulators abstaining from selective forbearance. Indeed, in the years immediately prior to the crisis there had been a 'paper' convergence with global standards of regulation that meant absolutely nothing in practice as regulations were implemented incredibly selectively (OECD 1996: 77-80; 1998: 58-66). An important step towards limiting regulatory forbearance and insuring regulations were consistently enforced was taken with the creation of an independent universal regulator in 1998. ${ }^{11}$

The Act establishing an independent financial regulator (the FSS) makes it very clear that this institution enjoys a high degree of independence from direct political control and will refrain from regulatory forbearance. Although the executive board (the Financial Services Commission (FSC)) that determines the policies and monitors the performance of the FSS is situated within the Prime Minister's office it 'performs its duties independently of any government organisation' (FSC 2000: 25). While politicians had previously controlled the instruments of financial regulation, the FSC is principally composed of independent members appointed for a fixed term over whom the executive exercises no effective control. ${ }^{12}$ Moreover, the powers, at least formally, delegated to the FSC are considerable, to quote:

As part of its regulatory responsibilities, the FSC deliberates and resolves policy making matters relating to the inspection and supervision of financial institutions and the securities and futures market. The FSC also has the authority to issue and revoke licences to financial institutions. This gives the FSC unrestricted jurisdiction to carry out its tasks efficiently and effectively. (ibid.: 25)

By placing such an autonomous and powerful organisation at the heart of the post-crisis process of financial re-regulation, the Korean state sent out a clear signal about its intentions to create an 'appropriately' regulated market-based financial system. ${ }^{13}$

The importance of the creation of FSC in imposing a new regime of financial discipline can be best understood when we consider it alongside central bank reform. Historically, the central objective of monetary policy in Korea was essentially a microeconomic one. Through a plethora of rediscounting and support operations the bank sought to ensure that sufficient funds were channelled towards chosen projects and economic actors. The decision to grant operational autonomy to the bank and instil it with a clear legal mandate to uphold market neutrality represented an important step towards cutting off the automatic supply of credit that politically connected firms had previously enjoyed (Matthews 1998: 755). In other words, it represented an important part of the process of disciplining key domestic firms.

The ultimate proof of the effectiveness of the financial reform measures that have been implemented since the crisis is to be found in the number of financial institutions which have collapsed and the difficulties that major unprofitable firms have experienced when attempting to attract finance. The fact that a clear break with the previous longstanding consistent generalised informal policy of regulatory forbearance has taken place is demonstrated by the sheer scale of the (creative) destruction that has occurred in the financial sector since 1997. Only five of the 17 nationwide commercial banks operating on the eve of the crisis were still operating in 2002 (OECD 1999: 88; Richards et al. 2002: 102). Furthermore, there 
is evidence that, as a result of regulatory changes, Korean financial institutions are making a serious attempt to scrutinise the financial structures of large firms before extending credit. Firm level analysis by Borensztein and Lee (2002) clearly demonstrates that the chaebol lost their preferential access to finance in the wake of the crisis and that a reallocation of credit towards more profitable firms is taking place. More anecdotally, the experience of the Daewoo group and Hyundai Heavy Industries both of whom have effectively gone bankrupt illustrates that size/repetition is no longer a guarantee of credit.

None of this proves that systems of financial regulation are flawless or that regulatory forbearance is simply a thing of the past. Nor is it intended to suggest that Korean financial institutions have developed particularly sophisticated credit cultures. They have not. What it does strongly suggest is that regulatory reform has, nevertheless, led to profound changes in the way that financial institutions operate and created the basis for an effective market based financial system to develop.

The comprehensive reform of systems of corporate governance and financial regulation in Korea has implications that reach far beyond Korea itself. The concluding section of this paper focuses on the broader significance of our analysis of Korea for debates on globalisation and development.

\section{Conclusion}

If the arguments advanced within this paper stand up to scrutiny their implications for our understanding of both the development of the Korean political economy and the viability of state-led late development projects in the contemporary global economy are considerable. The paper clearly argues that a new unambiguously neo-liberal regulatory regime is now consolidated within Korea. The fact that Korea, the great exemplar of state-led capitalist development, has reconfigured itself along neo-liberal lines is significant enough. The full implications of this reconfiguration can only be fully drawn out by highlighting the role that the 1997 crisis and global structural change has played in this process.

There exists a rich theoretical literature dominated by Marxists of various hues and scholars influenced by Schumpeterian evolutionary economics that understands crisis as an integral part of capitalist development (Kleinknecht 1990; Mandel 1978; Reijnders 1997; Albritton 2001). However, within the literature focused on Korea the 1997 crisis is at least implicitly portrayed as an aberration which must be explained in terms of policy mistakes, external political pressures or the economic effects of democratisation (Bello et al. 1999; Weiss 2000; Emery, 2001; Kang 2002). This paper offers a distinctive argument. The crisis must, we argue, be understood as an integral part of the process of creating a new neo-liberal mode of regulation fully attuned to the dictates of competitiveness within the contemporary global economy. Our analysis of the crisis itself will have a significant impact not only on our understanding of the subsequent development of the Korean political economy but on debates on neo-liberal reform globally.

Mainstream neo-classical economics maintains that the numerous crises that have accompanied the liberalisation process globally can be attributed to technical problems of implementation, a failure to develop proper regulatory institutions and, most fashionably of all, to sequence reform in a prudent and logical manner. ${ }^{14}$ This is as true of supposedly heterodox 'post neo-classical' scholars such as Stiglitiz (2003) as it is the mandarins of the World Bank/IMF. While this paper does not represent either the first or the most important 
study to challenge these assumptions it does, nevertheless, make an important contribution to this body of literature by demonstrating how crisis had to accompany liberalisation in a major centre of global accumulation.

At the same time, however, this paper highlights the serious problems that global structural change poses for state-led late development projects. The material basis for the continuation of relatively autocentric late development projects, such as that pursued by Korea in the 1960-70s and Japan in the 1950-60s, based upon the development of independent exporting capacity/ industrial self-sufficiency is increasingly being undermined. Despite all the problems and instabilities associated with neo-liberal capitalism, and particularly the transition to a more liberal model, there would seem to be little alternative to promoting economic openness for underdeveloped states seeking to become significant sites of accumulation in the contemporary global economy. There are no easy answers for developing states that have historically pursued relatively autocentric state-led development strategies. On the one hand, there is absolutely no guarantee that liberalisation will be successful and even if liberalisation is ultimately successful the unavoidable social and economic costs of transition may be severe. On the other hand, however, to fail to liberalise is likely to have serious long-term consequences for national competitiveness.

\section{Notes}

1 The next two and a half paragraphs are based on Pirie (2005a; 2005b).

2 This heavy reliance on external funds was also both a product and a cause of the pathologically low profitability of the Korean corporate sector. We shall expand on this point later in the paper.

3 Questions relating to the cost of capital are not necessarily identical to those pertaining to the availability of capital. Nevertheless, they are symbiotically linked in that an obvious form in which a shortage of capital is likely to manifest itself is in high long-term interest rates.

4 Although state-institutionalists scholars would also stress the importance of the failure to retain selective capital controls in order to curb the speculative excesses of the global financial markets (Thurbon 2003). Nevertheless, these scholars do not dissent from the position that the failure to discipline domestic capital lay at the heart of the crisis.

5 The chaebol are the massive conglomerates that collectively dominate the leading sectors of the Korean economy.

6 Institutions such as the IMF and OECD can also be understood as playing a important role in the process of neo-liberal regulatory reform due to the role they play in constructing internationally recognised 'standards of best practice'. Standards that, as we argue later in this paper, the Korean state has consistently sought to benchmark its reforms efforts against.

7 Baek et al. (2004) present a strong argument, based upon econometric analysis, that there was a significant link between standards of corporate governance and firm performance in pre-crisis Korea. Firms with greater levels of transparency and powerful external monitoring agents (foreign institutional investors) enjoyed higher profitability than their less transparent counterparts who did not possess effective external monitoring agents.

8 In a different national context it may be perfectly reasonable to discuss corporate governance in isolation from corporate profitability. However, as we already have made clear, given that in Korea controlling shareholders had, in the absence of effective market or non-market based checks on their behaviour, long subordinated the pursuit of ordinary profitability to other objectives it is necessary to analyse corporate profitability alongside governance issues. Resolving governance problems was key to improving firms' financial performance. 
9 IRC ratios are a measure of firms' capacity to meet interest expenses out of current operating profits. An IRC ratio of less than 100 per cent would indicate that a firm is unable to meet these expenses using only current operating profits.

10 Of course it is possible to argue that Korean profitability statistics are likely to be distorted by poor accounting standards. However, even if this is true the historical comparisons between pre- and post-crisis Korea remain valid. Nobody would argue that standards of accounting/ transparency are worse in contemporary Korea than they were prior to the crisis.

11 The analysis of central bank reform and the creation of an independent financial regulator offered here are based upon Pirie (2005b).

12 Five of the nine members of the FSC are appointed directly by the President and enjoy security of tenure. The Deputy Head of the BOK and the Korean Deposit Insurance Corporation, both civil servants, and the Deputy Minister of Finance and Economy also sit on the FSC. The members of the FSC are expected to follow certain 'operating principles'. These principles include an obligation to operate in a transparent manner, harmonise Korean standards with international norms, protect financial consumers, respect the autonomy of private institutions, strengthen prudential standards and take swift action against institutions which fail to meet these standards (FSC 2000: 3-35).

13 Questions have, however, been raised about the extent to which the FSC is, in practice, independent from political control. The World Bank reports that 'concerns arise because of the role taken by MOFE in interpreting law and supervisory regulation, giving the FSC only limited freedom in implementing supervision' (World Bank 2003). We should take the World Bank's carefully measured criticisms seriously. However, the fact that the autonomy of the FSC may in some relatively limited way be compromised does not undermine the argument presented here that the creation of such an institution is a development of first order importance.

14 We use the term 'mainstream neo-liberal' rather than 'neo-liberal' in order to clearly exclude neo-Schumpeterian scholars.

\section{References}

Albritton, R., Itoh, M., Westra, R. and Zuege, A. (eds) (2001) Phases of Capitalist Development: Booms, Crisis and Globalizations (London: Palgrave).

Amsden, A. (1989) Asia's Next Giant: South Korea and Late Industrialisation (Oxford: Oxford University Press).

Balifio, T.E. and Ubide, A. (1999) The financial crisis - A strategy of financial sector reform', Working Paper, No. 99/28, Washington, IMF.

Baek, J-S., Kang, J-K. and Park, K. (2004) Corporate governance and firm value: evidence from the Korean financial crisis, Journal of Financial Economics, 71: 265-313.

Bello, W. with Cunningham, S. and Rau, B. (1999). Dark Victory: The United States and Global Poverty, 2nd edn (London: Pluto Press).

BOK (Bank of Korea) (2003) Financial statement analysis 2002. (http://www.bok.or.kr/content/old/ attach/00000716/200308061418020.pdf).

BOK (Bank of Korea) (2004) Financial statement analysis 2003. (http://www.bok.or.kr/contents _adim/eng/home/public/public07/info/The OutlineandThe ResultsoftheFSA2003.pdf).

BOK (Bank of Korea) (2005) Financial statement analysis 2004. (http://www.bok.or.kr/contents _admin/info_admin/eng/home/public/public07/info/TheOutlineandTheResultoftheFSA.pdf).

Bonefeld, W. (1993) The Recomposition of the British State During the 1980s (Aldershot: Ashgate).

Borensztein, E. and Lee, J-W. (2002) Financial crisis and credit crunch in Korea: evidence from firms-level data, Journal of Monetary Economics, 49: 853-875.

Chang, H-J., Park, H-J. and Yoo, C-G. (1998) Interpreting the Korean crisis: financial liberalisation, industrial policy and corporate governance, Cambridge Journal of Economics, 22: 735-746. 
Chang, S-J. (2003) Financial Crisis and Transformation of Korean Business Groups: The Rise and Fall of Chaebols (Cambridge: Cambridge University Press).

Chang, H-J. and Park, H-J. (2004) An alternative perspective on government policy towards the chaebol in Korea: industrial policy, financial regulation and political democracy, Competition and Corporate Governance in Korea: Reforming and Restructuring the Chaebol (Cheltenham: Edward Elgar), pp. 24-61.

Cho, M-H. (2003) Reform of corporate governance, in S. Haggard, S. Kim, and E. Yim (eds), Economic Crisis and Corporate Restructuring in Korea (Cambridge: Cambridge University Press), pp. 286-306.

Chung, K.S. and Wang, Y.K. (2001) Republic of Korea, in J. Zhuang, D. Edwards and V. Capulong (eds), Corporate Governance and Finance in East Asia: A Study of Indonesia, Republic of Korea, Malaysia, Philippines, and Thailand, 2 (Manila: Asian Development Bank), pp. 53-154.

Clarke, S. (1992) The global accumulation of capital and the periodisation of the capitalist state form, in W. Bonefeld, R. Gunn and K. Psychopedis (eds), Open Marxism, 1: History and Dialectics (London: Pluto Press), 133-150.

Crotty, J. and Lee, K-K. (2004) Was the IMF's Imposition of Regime Change in Korea Justified? A Critique of the IMF's Economic and Political Role in Korea during and after the Crisis, Working Paper, No. 77, Political Economy Research Centre, University of Massachusetts Amherst (http://www-unix.oit.umass.edu/ crotty/WP77.pdf).

Dicken, P. (1998) Global Shift: Transforming the World Economy, 3rd edn (London, Paul Chapman).

Dicken, P. (2003) Global Shift: Reshaping the Global Economic Map in the 21 $1^{\text {st }}$ Century, 4th edn (London: Sage).

Dunning, J. (1993) The Globalization of Business (London: Routledge).

Dunning, J. (1997) Alliance Capitalism and Global Business (London: Routledge).

Emery, R. (2001) Korean Economic Reform: Before and Since the 1997 Crisis (Aldershot: Ashgate).

FSC (Financial Supervisory Commission) (2000) Financial Reform \& Supervision in Korea (http:// www.fsc.go.kr).

FSS (Financial Supervisory Service) (2000) Financial Supervisory System in Korea (http://www. fss.or.kr).

Gills, B. (1996) Economic liberalisation and reform in South Korea in the 1990s: a 'coming of age' or a case of 'graduation blues'?, Third World Quarterly, 17(4): 667-688.

Gobat, J. (1998) Republic of Korea: Selected Issues, IMF Country Issues, 98/74 (Washington, IMF).

Graham, E. (2003) Reforming Korea's Industrial Conglomerates (Washington: Institute for International Economics).

Haggard, S., Lim, W. and Kim, E. (eds) (2003) Economic Crisis and Corporate Restructuring in Korea (Cambridge: Cambridge University Press).

Hahm, J-H. (2003) The government, the chaebol and financial institutions before the economic crisis, in S. Haggard, W. Lim, and E. Kim (eds), Economic Crisis and Corporate Restructuring in Korea (Cambridge: Cambridge University Press), pp. 79-102.

Hahm, J-H. (2004) Financial restructuring, in D-K. Chung and B. Eichengreen (eds), The Korean Economy Beyond the Crisis (Cheltenham: Edward Elgar), pp. 172-192.

IMF (International Monetary Fund) (2003) Republic of Korea: 2002 Article IV Consultation; Public Information Notice on the Executive Board Discussion; and Statement by the Executive Director for Korea, IMF Country Report, 03/79 (Washington: IMF).

Jang, H. and Kim, J. (2002) Nascent stages of corporate goverance in an emerging market: regulatory change, regulatory change, shareholder activism and Samsung Electronics, Corporate Governance, 10(2): 94-105.

Jessop, B., Bonnett, K., Bromley, S. and Ling, T. (1988) Thatcherism: A Tale of Two Nations (Oxford: Polity Press).

Joh, S. (2001) 'The Korean corporate sector: crisis and recovery', in O.Y. Kwon and W. Shepherd (eds), Korea's Economic Prospects: From Financial Crisis to Prosperity (Cheltenham: Edward Elgar), pp. 116-132. 
Jwa, S-H. and Lee, I. (eds) (2004) Competition and Corporate Governance in Korea: Reforming and Restructuring the Chaebol (Cheltenham: Edward Elgar).

Kang, D. (2002) Crony Capitalism: Corruption and Development in South Korea and the Philippines (Cambridge: Cambridge University Press).

Kim, B. and Lee, I. (2003) Agency problems and performance of Korean companies during the Asian financial crisis: chaebol vs. non-chaebol firms, Pacific-Basin Financial Journal, 11: 327-348.

Kim, D-J. (1996) Mass-Participatory Economy: Korea's Road to World Economic Power (Revised and Updated Edition) (London: University Press of America).

Kim, K. and Jeong, S. (2000) Controlled the controlled shareholders: conduct, structure, and market, in D-K. Yoon (ed.), Recent Transformations in Korean Law and Society (Seoul: Seoul National University Press), pp. 153-170.

Kim Y. and Moon C-I. (2000) Globalisation and workers in South Korea: economic reform and labor, in Kim, S.S. (ed.), Korea's Globalization (Cambridge: Cambridge University Press), pp. 54-75.

Kim, Y-C. (1999) Explaining the change of state interest in financial liberalisation, Paper presented at Annual Conference, British International Studies Association, Manchester, 20-22 December.

Kleinknecht, A. (1987) Innovation Patterns in Crisis and Prosperity: Schumpeter's Long Cycle Reconsidered (London: Macmillan).

Kong, T. (2000) The Politics of Economic Reform in South Korea: A Fragile Miracle (London: Routledge).

Koo, J. and Maeng, K. (2005) The effects of financial liberalization on firms' investment in Korea, Journal of Asian Economics, 16: 281-297.

Lee, Y-H. (2000) The failure of the weak state in economic liberalization: liberalization, democratization and the financial crisis in South Korea, Pacific Review, 13(1): 115-131.

Lee, Y-H. and Kim, H-R. (2000) The dilemma of market liberalization: the financial crisis and the transformation of capitalism, in R. Robison, M. Beeson, K. Jayasuriya and H-R. Kim (eds), Politics and Markets in the Wake of the Asian Crisis (London: Routledge), pp. 116-130.

Lim, W., Haggard, S., and Kim, E. (2003) Conclusion: Wither the Chaebol, in S. Haggard, S. Kim and E. Yim (eds), Economic Crisis and Corporate Restructuring in Korea (Cambridge: Cambridge University Press), pp. 307-336.

Mandel, E. (1978) [1975] Late Capitalism (London: Verso).

Matthews, J. (1998) Fashioning a new model out of the Korean crisis: the rebuilding of institutional capacities, Cambridge Review of Economics, 22: 447-459.

Matthews, D. (2002) Globalising International Property Rights: The TRIPs Agreement (London: Routledge).

Ministry of Finance and Economy (Republic of Korean) (2004) Dynamic Korea: A Nation on the Move (Seoul: Ministry of Finance and Economy).

OECD (Organisation for Economic Co-operation and Development) (1996) Economic Survey of Korea (Paris: OECD).

OECD (Organisation for Economic Co-operation and Development) (1998) Economic Survey of Korea (Paris: OECD).

OECD (Organisation for Economic Co-operation and Development) (1999) Economic Survey of Korea (Paris: OECD).

OECD (Organisation for Economic Co-operation and Development) (2000a) Regulatory Reform in Korea (Paris: OECD).

OECD (Organisation for Economic Co-operation and Development) (2000b) Economic Survey of Korea (Paris: OECD).

OECD (Organisation for Economic Co-operation and Development) (2001a) Science, Technology and Industry Scoreboard (Paris: OECD).

OECD (Organisation for Economic Co-operation and Development) (2001b) Economic Survey of Korea (Paris: OECD). 
OECD (Organisation for Economic Co-operation and Development) (2004) Economic Survey of Korea (Paris: OECD).

Park, H.J. (2002). After dirigisme: globalization, democratization and the still faulted state and its social discontents in Korea, Pacific Review, 15(1): 63-88.

Pirie, I. (2005a) Better by Design: Korea's neoliberal economy, Pacific Review, 18(3): 1-20.

Pirie, I. (2005b) The New Korean State. New Political Economy, 10(1): 27-44.

Prakash, A. and Hart, J. (eds) (1999) Globalization and Governance (London: Routledge).

Reijnders, J. (1997) Economics and Evolution (Cheltenham: Edward Elgar).

Richards, A., Kang, K., Ma, H., Liang, H., Kalra, S., Win, T., Cashin, P., Karasulu, M., Laryea, T. and Cho, S. (2002) Korea: selected issues, IMF Country Issues, 02/20 (Washington: IMF).

Shin, J-S. and Chang, H-J. (2003) Restructuring Korea Inc. (London: Routledge).

Stiglitiz, J. (2003) Globalization and Its Discontents (London: Penguin).

Stopford, J. and Strange, S. (with Henley, J.S.) (1991) Rival States, Rival Firms (Cambridge: Cambridge University Press).

Strange, S. (1994) States and Markets, 2nd edn (London: Pinter).

Strange, S. (1998) Mad Money (Manchester: Manchester University Press).

Thurbon, E. (2003) Ideational inconsistency and institutional incapacity: Why financial liberalisation in South Korea went horribly wrong, New Political Economy, 8(3): 341-363.

Ungson, G., Steers, R. and Park, S-H. (1997) Korean Enterprise: The Quest for Globalization (Boston: Harvard University Press).

van Hoesel, R. (1999) New Multinational Enterprises from Korea and Taiwan (London: Routledge).

Weiss, L. (2000) Developmental states in transition: adapting, dismantling, innovating, not 'normalizing', Pacific Review, 13(1): 21-55.

Weiss, L. (2003) Guiding globalisation in East Asia: new roles for old developmental states, in L. Weiss (ed.), States in the Global Economy: Bringing Domestic Institutions Back In (Cambridge: Cambridge University Press), pp. 245-270.

World Bank (1997) World Development Report 1997: The State in a Changing World (Oxford: Oxford University Press).

World Bank (2002a) World Development Report 2002: Building Institutions for Markets (Oxford: Oxford University Press).

World Bank (2003) Korea: Financial Sector Assessment, Economic Report, No. 26176 (available at http:www-wds.worldbank.org).

Woo, J. (1991) Race to the Swift: State and Finance in Korean Industrialization (New York: Columbia University Press). 